\title{
Development of Low-Cost Activated Carbon towards an Eco-Efficient Removal of Organic Pollutants from Oily Wastewater
}

\author{
Rania Remmani $^{1 *}$, Rachid Makhloufi ${ }^{1}$, Malek Miladi ${ }^{2}$, Abdelkader Ouakouak ${ }^{3}$, \\ Antonio Ruiz Canales ${ }^{2}$, Dámaris Núñez-Gómez ${ }^{4}$
}

${ }^{1}$ Applied Chemistry Laboratory LCA, University of Biskra, PO Box 145, 07000 Biskra, Algeria

${ }^{2}$ Engineering Department, Miguel Hernández University, Carretera de Beniel, 03312-Orihuela, Alicante, Spain ${ }^{3}$ Research Laboratory in Subterranean and Surface Hydraulics, University of Biskra, PO Box 145, 07000 Biskra, Algeria ${ }^{4}$ Plant Production and Microbiology Department, Miguel Hernández University, Carretera de Beniel, 03312-Orihuela, Alicante, Spain

Received: 17 April 2020

Accepted: 27 July 2020

\begin{abstract}
The current study seeks to investigate the feasibility use of date palm kernels for the development of activated carbon (AC) towards its application, which functions as an adsorbent to treat oil-contaminated groundwater. Biochar derived from date palm kernels (BPK), was prepared by direct pyrolysis of the raw precursor at $600^{\circ} \mathrm{C}$ for 90 minutes (in oxygen-limited condition). Activated carbon (ACPK) included similar pyrolysis conditions of biochar with subsequent impregnation in $\mathrm{H}_{2} \mathrm{SO}_{4}$ (as activating agent) at a ratio of acid: biochar (1:1), moderate temperature. The analytical approach was performed through the use of XRD, BET, and FTIR, techniques to evaluate the effect of carbonization and activation process in improving the adsorptive properties of starting materials. Carbonaceous adsorbents obtained were highly porous due to their elevated specific surface area of $\left(333.4 \mathrm{~m}^{2} / \mathrm{g}\right.$ for BPK and $741.5 \mathrm{~m}^{2} / \mathrm{g}$ for ACPK) and their amorphous structure. Indeed, the textural proprieties were significantly improved by the acidic treatment. Further, the adsorption behavior of produced materials was tested by performing batch adsorption tests in contaminated water samples using a ratio of 1:1 $(\mathrm{g} / \mathrm{L})$ for 24 hours. The efficiency of adsorbents was evaluated by COD $(\mathrm{C} 0=8568 \mathrm{mg} / \mathrm{L})$, $\mathrm{BOD}_{5}(\mathrm{C} 0=200 \mathrm{mg} / \mathrm{L})$ concentration, $\mathrm{pH}$ and hardness values before and after the treatment. Removal efficiency of COD for the BPK and ACPK samples reached $82.6 \%$ and $95.2 \%$ respectively, while for $\mathrm{BOD}_{5}$ was the same $(97.0 \%)$ for both adsorbents. Additionally, the treated water sample has the same excellent class suitable for irrigation applications according to the Wilcox diagram. In consequence,
\end{abstract}

*e-mail: rania.remmani@univ-biskra.dz 
the present study suggests an effective, eco-friendly and economical adsorption process intending to mitigate environmental risk sustainably.

Keywords: environmental remediation, agro-waste, activated carbon, pollutant uptake, water quality, irrigation

\section{Introduction}

Toxic pollutant contents in aquatic environments become a thoughtful issue for human health and ecological systems. Several industrial activities worldwide discharge harmful wastewaters without any treatment. For instance in the case of Algeria, water quality adversely affected by petroleum industry growth. Processing operations in Skikda, Arzew, and Algiers oil refineries, constitute the major source of oily wastewater pollution besides to the losses in transport terminals during exportation of petrochemicals to Mediterranean destinations [1]. Several chemicals like sulfides, phenol, ammonia, and hydrocarbons may found in released petroleum refinery effluents (PRE) at different concentrations. Meanwhile, effluent's composition differs depending on several factors including the type of processed crude, operational methods, and plant configuration [2]. The occurrence of these hazardous pollutants leads to a number of environmental-health and ecological issues in addition to socio-economic difficulties [3-6].

Henceforth, to evade the coming issues associated with water scarcity, the treatment of those industrial effluents until non-risk values are needed before their discharge into waterways. For this motive, various conventional technologies have been utilized for pollutants removal from the aquatic medium like coagulation [7], air flotation [8], chemical oxidation [9], biological treatment [10] and adsorption [11]. In the same vein, novel treatment approaches have been developed recently such as membrane technology [12] and microwave-assisted catalytic wet air oxidation [13]. Particularly, adsorption seems quite attractive due to its efficiency, lower costs and no secondary pollution [14]. The process by which ions, atoms or molecules of liquids, gases or dissolved solids are retained on a specific surface is known as adsorption, where the surface material is named as adsorbent while adsorbate is the substance that will be adsorbed. The selection of adsorbent based first on its porous structure which provides a larger surface area and on its ability to show rapid adsorption kinetics [15]. Activated carbon, Chitosan-based polyacrylamide and polypropylene were used as adsorbents for the treatment of oily wastewater [16]. Among bio-adsorbents, carbonaceous materials are considered as the most popular adsorbent and attracted more attention in the existing literature due to its attractive adsorption characteristics [17]. However, using unrenewable raw materials for activated carbon (AC) production such as coal carbon increases its costs and restricts its use. Therefore, the reduction of the AC production costs is crucial to develop its use for wastewater treatment applications. In this regard, several agricultural by-products like wood [18], tomato stem [19], banana peel [20], olive stones [21], and carrot waste [22] have been employed as a low-cost precursor to developing green and efficient AC. In Algeria, a large amount of date palm kernels is generated annually without any valorization, which may serve as a good source of carbonaceous materials. Thus, developing the use of date seeds as locally available material for AC production could be considered as an optimal decision towards minimizing input costs and solving waste disposal issues.

This work investigates the development of biochar form date palm kernels (BPK) and activated carbon date palm kernels (ACPK) and highlights their potential to treat contaminated groundwater by oil pollution. The BPK and ACPK samples were characterized by Fourier transform infrared spectroscopy (FTIR), X-ray diffraction (XRD) and BrunauerEmmett-Teller (BET) techniques. The adsorption tests were performed in batch manner. The adsorption efficiency was evaluated based on the measurements of the chemical and bio-chemical oxygen demand (COD and $\mathrm{BOD}_{5}$ respectively). Various physico-chemical characteristics of treated water samples were also analyzed and compared to the irrigation standards obtained from the free software database. "Diagrammes version 6.61" developed by Laboratoire d'Hydrogéologie d'Avignonand available in http://www.lha.univ-avignon.fr/LHA-Logiciels.htm.

\section{Materials and Methods}

\section{Material and Reagents}

All reagents used in this work have reagent grade (99\%) and purchased from Sigma-Aldrich. Other additives such as $\mathrm{HCl}(0.1 \mathrm{M})$ or $\mathrm{NaOH}(0.1 \mathrm{M})$ were used to adjust the $\mathrm{pH}$ of solutions. All solutions were prepared with deionized water and all chemicals were used without further purification. The groundwater samples used in this study are from Illizi region, Algeria $\quad\left(26^{\circ} 30^{\prime} 33.965^{\prime \prime} \mathrm{N}, \quad 8^{\circ} 28^{\prime} 23.778^{\prime \prime} \mathrm{E}\right)$. This water has been contaminated with oil by extraction from local wells. The combination of extracted oil with groundwater produced many changes due to oil composition modifications including the low-molecularweight fractions spontaneously evaporated, the soluble 
components dissolved into contaminated water, the oil droplets combined with water, and photochemical oxidation and biodegradation happened to specific oil elements and not all of it [23].

\section{Raw Date Kernel Precursor}

Kernels of the "Deglet Noor" cultivar was selected as a cheap feedstock for the production of adsorbents. The starting material was cut into small pieces, washed with hot distilled water, dried at $75^{\circ} \mathrm{C}$ (for 24 hours) and then sieved to sizes between 0.08 and $0.25 \mathrm{~mm}$. The biochar (BPK) was prepared through a direct pyrolysis of the obtained powder at $600^{\circ} \mathrm{C}$ (rate of $10 \% \mathrm{~min}$ ) for 90 minutes using a conventional furnace. On the other hand, activated carbon (ACPK) was made following the same methodology applied for biochar sample but after impregnation of powder in sulfuric acid $5 \mathrm{~N}$ (for 4 hours at $50^{\circ} \mathrm{C}$ ). After cooling at room temperature, the obtained biochar was soaked in $\mathrm{HCl}$ solution $(0.1 \mathrm{M})$. After that, both BPK and ACPK samples were washed with deionized water until neutral $\mathrm{pH}$ of filtrate (i.e. $\mathrm{pH}$ 6.5-7.5). Finally, the obtained materials were dried at $75^{\circ} \mathrm{C}$ for 24 hours, ground and sieved to obtain a powder with $0.1-0.8 \mathrm{~mm}$ of particle size.

\section{Characterization of Adsorbents}

The morphological and chemical properties of the adsorbent samples were studied by Fourier transform infrared spectroscopy (FTIR), X-ray diffraction (XRD) and Brunauer-Emmett-Teller (BET) techniques. The functional groups of the adsorbentss surface were identified using Perkin Elmer Spectrometer (Spectrum Two) to determine the chemical structure of produced AC. FTIR spectra were recorded in wave number range of $400-4000 \mathrm{~cm}^{-1}$. Phase state of BPK and ACPK samples were determined through XRD distribution by use of "Brucker D-8 advance diffractometer" with $\mathrm{CuK} \alpha$ radiation $(1=1.5406 \AA)$ at $30 \mathrm{~mA}$ and $40 \mathrm{kV}$. The $\mathrm{N}_{2}$ adsorption-desorption isotherm determined apparent surface area and particle size of carbonaceous materials (BPK and ACPK) at $373 \mathrm{~K}$ for 10 hours (Micromeritics ASAP 2020).

\section{Adsorption Experiments}

Adsorption tests were performed by using $250 \mathrm{~mL}$ glass Erlenmeyer flask (Pyrex). In each Erlenmeyer, $100 \mathrm{~mL}$ of groundwater sample was mixed with $100 \mathrm{mg}$ of adsorbent (BPK - ACPK). The mixture was stirred in a Horizontal mechanical shaker $(200 \mathrm{rpm})$ for 24 hours and at room temperature $(295 \pm 1 \mathrm{~K})$. After that, solutions were filtered by Buchner filtration flask using membrane filter (pore size of $45 \mu \mathrm{m}$ ). The result was obtained from the average of three duplicated assays for each adsorption experiment.

\section{Analysis of Groundwater Samples}

Groundwater samples were characterized before and after adsorption treatment to examine the efficiency of BPK and ACPK adsorbents in removing water pollutants. The evaluation of water organic pollution was based on the measurement of biochemical oxygen demand for 5 days $\left(\mathrm{BOD}_{5}\right)$ and chemical oxygen demand $(\mathrm{COD})$ of water samples. The $\mathrm{BOD}_{5}$ and $\mathrm{COD}$ measurements were performed on BOD OxiTop Thermostat Box (WTW) and COD3 plus Colorimeter (LaMotte) respectively. The efficiency of pollutant removal (\% Removal) from water samples was calculated as shown in Eq. 1.

$$
\% \text { Removal }=\frac{C_{I}-C_{F}}{C_{I}} \times 100
$$

...where $\mathrm{C}_{\mathrm{I}}$ and $\mathrm{C}_{\mathrm{F}}(\mathrm{mg} / \mathrm{L})$ are the initial and the final pollutant concentration, respectively.

The groundwater suitability for irrigation was determined according to the Wilcox Diagram which based on the electrical conductivity value and the sodium adsorption-ratio $(\% \mathrm{Na})$. This parameter is calculated from Eq. 2 (cations concentrations are expressed in $\mathrm{meq} / \mathrm{L}$ ):

$$
\% N a=\frac{N a^{+}+K^{+}}{\mathrm{Ca}^{2+}+M g^{2+}+N a^{+}+K^{+}} \times 100
$$

The Wilcox diagram suggests that the quality of irrigation water can be excellent, good, permissible, doubtful, or unsuitable. This diagram shows that the water quality a decreases with increasing the $\% \mathrm{Na}$ and electrical conductivity values [24, 25].

The interest ions studied in the water samples were determined by three different techniques: titration technique for alkalinity, hardness, and chloride; sodium and potassium was determined by a flame photometer (PFP-7 Jenway); and a UV-vis spectrometer (LAMBDA 25 Perkin Elmer) was used for nitrate and sulfate determination.

In addition, $\mathrm{pH}$ and conductivity values were measured at room temperature $(295 \pm 1 \mathrm{~K})$ using $\mathrm{pH}$ meter (CyberScan $\mathrm{pH}$ 510) and conductivity meter (CON 510 conductivity/TDS) respectively.

\section{Hydrochemical Analysis}

Aiming to identify the quality aspects of the water samples the Piper diagram was used. This diagram is based on the premise that cations and anions in water are generally in chemical equilibrium. Water samples shown on the Piper diagram can be grouped in hydrochemical facies. Additionally, the hydrochemical data have been processed using the method of classification of Stabler. Stabler classification compares 
reaction quantities of cations and anions expressed as percentages (\%) and separately classifies the anions and cations in descending order to determine the chemical facies. Berkaloff Schöeller diagram was also used for water samples comparison with similar facies but different dilutions. All the hydrochemical diagrams were developed using "Diagrammes" software version 6.61 .

\section{Results and Discussions}

\section{Characterization of Adsorbents}

FTIR spectra give information about the surface proprieties of adsorbent samples. FTIR spectra of BPK and ACPK adsorbents were recorded in Fig. 1. The wide band observed in the range of $3150-3650 \mathrm{~cm}^{-1}$ is due to the hydroxyl groups $(-\mathrm{OH})$ stretching vibrations in the carbonaceous materials structure or adsorbed water. In this region, the $-\mathrm{OH}$ band in BPK sample is stronger than the ACPK one, which is attributed to the replacement of water molecules in the porous structure by the activating agent after $\mathrm{H}_{2} \mathrm{SO}_{4}$ activation of Biochar. The weak peak around at $1500-1750 \mathrm{~cm}^{-1}$ is related to stretching of $\mathrm{C}=\mathrm{C}$ bands in the aromatic carbon structure. The presence of $\mathrm{C}-\mathrm{H}$ of $-\mathrm{CH}_{3}$ and $-\mathrm{CH}_{2}$ of aromatic rings is confirmed by the peaks between 1400 and $1470 \mathrm{~cm}^{-1}$ for BPK and ACPK samples. The broad band observed in the region of $1000-1250 \mathrm{~cm}^{-1}$ represent the characteristic vibrations of $-\mathrm{OH}$ groups [26]. Moreover, the peak at $1150 \mathrm{~cm}^{-1}$ corresponds to the C-O stretching vibrations [27].

The BET analysis shows that both of biochar and activated carbon exhibit a well-developed porous structure. The BET surface area reached value of 333.4 (for BPK) to $741.5 \mathrm{~m}^{2} / \mathrm{g}$ (for $\mathrm{ACPK}$ ). This result confirms that the chemical activation improve significantly the textural property of biochar. During activation or carbonization at high temperature, the polymeric structures of the biomass decompose and

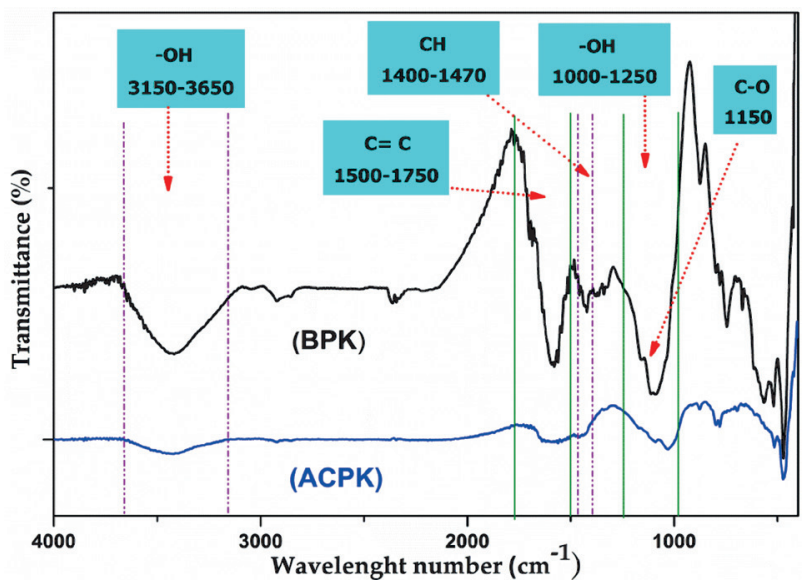

Fig. 1. FTIR spectra of BPK and ACPK samples.

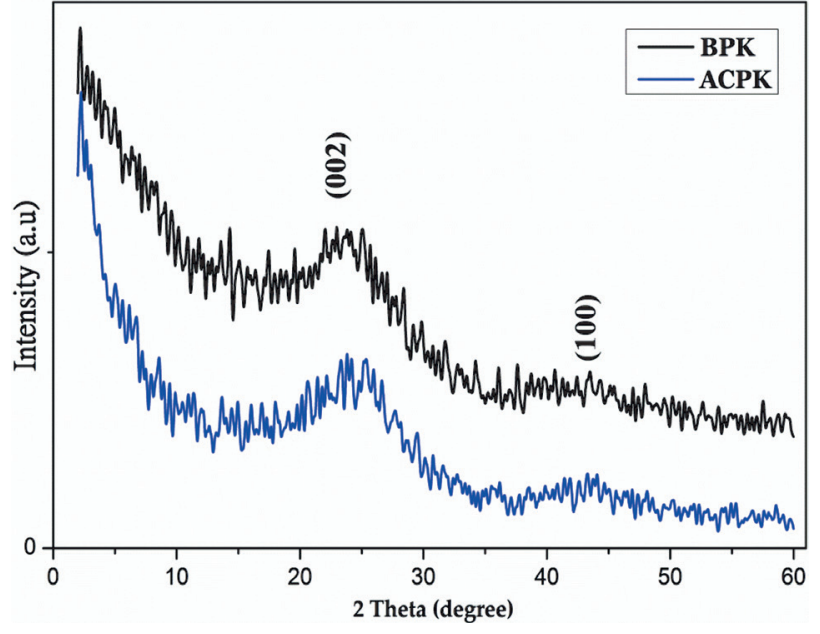

Fig. 2. X-ray diffraction pattern of BPK and ACPK samples.

liberate most of the non-carbon elements $\left(\mathrm{H}_{2}, \mathrm{O}_{2}\right.$ and $\mathrm{N}_{2}$ ), leaving behind a rigid carbon skeleton in the form of aromatic sheets and strips. It was also found that the average particle size was $179.5 \mathrm{~nm}$ (for BPK) and $17.6 \mathrm{~nm}$ (for ACPK). X-ray powder diffraction patterns of the biochar (BPK) and activated carbon (ACPK) samples are provided in Fig. 2. The noncrystallinity of carbon materials structure is confirmed by the absence of sharp reflections in the two patterns. The two broad reflections at near $2 \theta=26^{\circ}$ and $42^{\circ}$ are assigned to the (002) and (100) planes of graphite crystalline, respectively [28, 29]. The $d$-spacing value of the (002) plane was found to be $0.391 \mathrm{~nm}$ (for PBK) and $0.357 \mathrm{~nm}$ (for ACBK), which is very close to values reported in literature $[30,31]$.

\section{Characterization of Groundwater}

Fig. 3 shows the efficiency of adsorbents in removing $\mathrm{COD}$ and $\mathrm{BOD}_{5}$ from contaminated groundwater and $\mathrm{pH}$ of treated water. The COD removal efficiency of BPK and ACPK samples was $82.6 \%$ and $95.2 \%$ (initial $\mathrm{COD}=8568 \mathrm{mg} / \mathrm{L}$ ). This result confirms that the carbonaceous material exhibits a high adsorption capacity of COD after the chemical activation, which can be related to the development of their textural proprieties (surface area and total pore volume). The $\mathrm{BOD}_{5}$ removal efficiency was the same for both adsorbents $(97.0 \%)$ at initial $\mathrm{BDO}_{5}$ concentration of $200 \mathrm{mg} / \mathrm{L}$ and stirring time of $24 \mathrm{~h}(200 \mathrm{rpm})$. For the two adsorbents (BPK and ACPK), the overall adsorption efficiency is excellent for the $\mathrm{BOD}_{5}$ removal. This is due to the adsorption of a large fraction of biodegradable organic matter by the employed adsorbents. From results, the ACPK has the high organic adsorption capacity for COD parameter (COD: $95.2 \%$ ), but for the $\mathrm{BOD}_{5}$ both adsorbents have the same efficiency (97.0\%).

Furthermore, the $\mathrm{pH}$ value of the raw groundwater sample was 5.15, which indicates the acidic nature of this water, its tendency to corrosion and it can cause other 


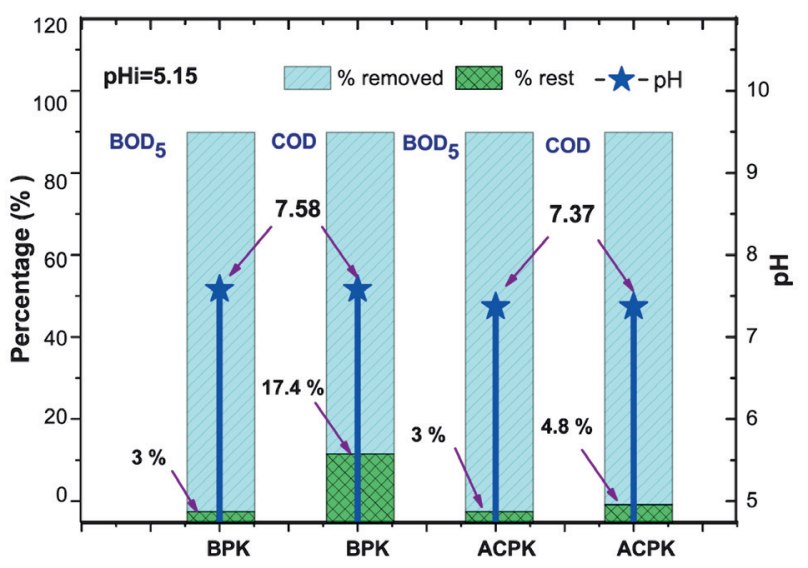

Fig. 3. $\mathrm{COD}, \mathrm{BOD}_{5}$ and $\mathrm{pH}$ results of the treated groundwater samples $\left(\mathrm{pH}_{\mathrm{i}}=5.15,\left[\mathrm{BOD}_{5}\right]_{\mathrm{i}}=200 \mathrm{mg} / \mathrm{L},[\mathrm{COD}]_{\mathrm{i}}=8568 \mathrm{mg} / \mathrm{L}\right)$.

environmental problems. In addition, the adsorption treatment of contaminated water presents the advantage of increasing the $\mathrm{pH}$ value towards neutrality, and the $\mathrm{pH}$ of treated water oscillates between 7.37 and 7.58. Values of the $\mathrm{BOD}_{5} / \mathrm{COD}$ ratio for the raw and treated water samples are less than 0.3 (Table 1), which confirm the non-biodegradable nature of the oil contamination, it is therefore compulsory to treat this groundwater with a physicochemical technique such as adsorption. The adsorption decreases the $\mathrm{BOD}_{5} / \mathrm{COD}$ ratio due to the efficiency of biologically oxidized organic pollution removal more than chemically oxidized organic pollution for both BPK and ACPK. This treatment shows also a decrease in the calcium hardness, such that after adsorption test, those adsorbents have a weak ability to soften the hardness of raw water. This treatment also shows decreased calcium hardness; nevertheless, those adsorbents poorly soften the hardness of raw water.

\section{Assessment of Groundwater Quality}

\section{Hydrochemistry}

In this study, Piper, STABLER and Schöeller Berkaloff diagrams are constructed to evaluate the variation in hydrochemical facies of water samples (Figs 4-6). The tendency of the cations for the raw and ACPK treated water samples is in order to: $\mathrm{Na}^{+}>\mathrm{Mg}^{2+}>$ $\mathrm{Ca}^{2+}>\mathrm{K}^{+}$, and for the BPK treated water is in order to: $\mathrm{Na}^{+}>\mathrm{Mg}^{2+}>\mathrm{K}^{+}>\mathrm{Ca}^{2+}$. As shown in Fig. 4, sodium is the dominant cation on all water samples. The tendency

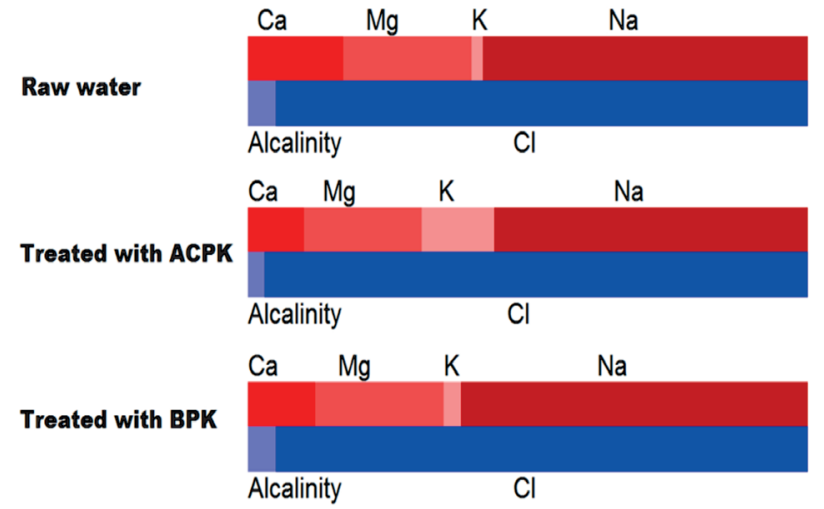

Fig. 4. STABLER diagram illustrating major ionic dominance in all water samples.

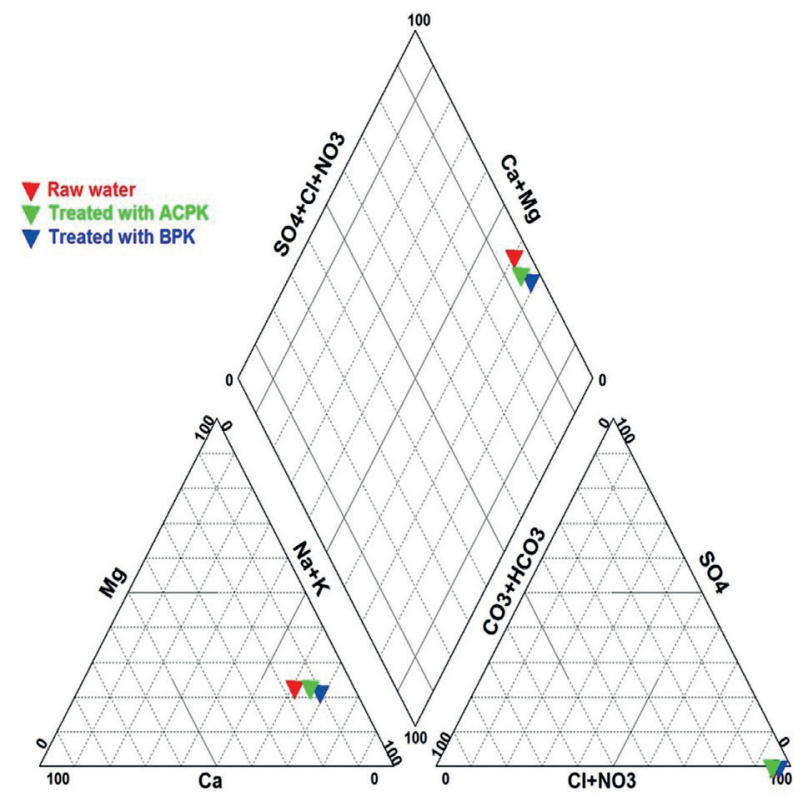

Fig. 5. Piper diagram of all water samples.

of the anions is in order to: $\mathrm{Cl}^{-}>$alkalinity and the dominant anion is chloride. The hydrochemical facies/ water types are the same (sodium chloride type) and influence only by geochemistry of the groundwater (Figs 4 and 5). The Piper diagram also shows that sodium (60\%) and chloride $(90 \%)$ are the most dominant ions and without the presence of sulfate anion on all water samples. The Schöeller Berkaloff diagram (Fig. 6) highlights very similar trends between the

Table 1. Parameters of raw and treated water samples.

\begin{tabular}{|c|c|c|c|c|c|c|}
\hline \multirow{2}{*}{ Water sample } & \multirow{2}{*}{$\begin{array}{c}\mathrm{BOD}_{5} \\
(\mathrm{mg} / \mathrm{L})\end{array}$} & \multirow{2}{*}{$\mathrm{COD}(\mathrm{mg} / \mathrm{L})$} & \multirow{2}{*}{$\mathrm{BOD}_{5} / \mathrm{COD}$} & \multirow{2}{*}{$\mathrm{pH}$} & \multicolumn{2}{|c|}{ Hardness (ppm) } \\
\hline & & & & & $\mathrm{Ca}^{2+}(\mathrm{mg} / \mathrm{L})$ & $\mathrm{Mg}^{2+}(\mathrm{mg} / \mathrm{L})$ \\
\hline Raw water & 200 & 8568 & 0.023 & 5.15 & 50 & 70 \\
\hline Treated with BPK & 6 & 1491 & 0.004 & 7.58 & 32 & 68 \\
\hline Treated with ACPK & 6 & 411 & 0.015 & 7.37 & 38 & 72 \\
\hline
\end{tabular}




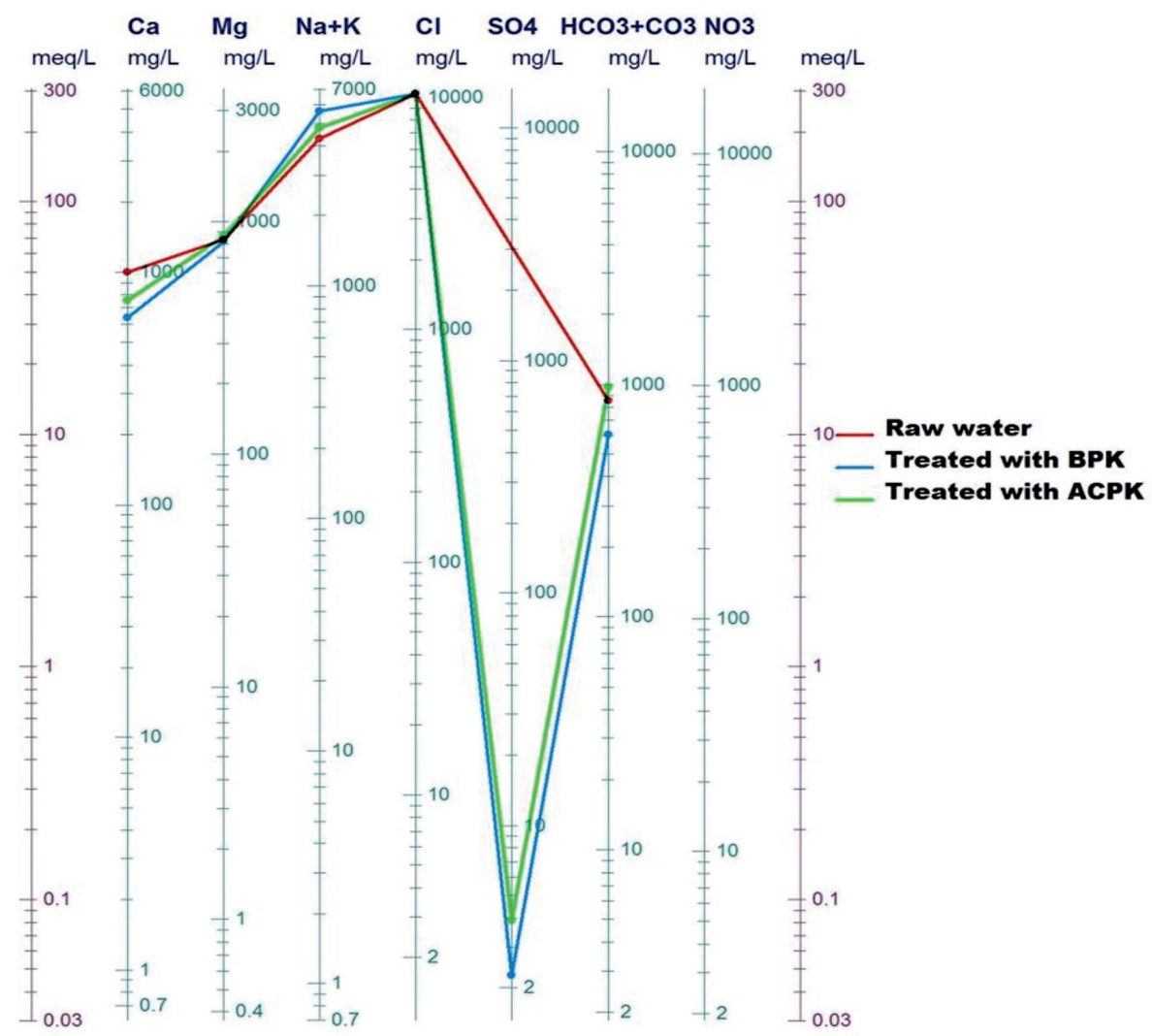

Fig. 6. Schöeller Berkaloff diagram of all water samples.

studied groundwater samples, in particular with deferent sulfate concentration on the raw water sample, confirming the results obtained by using Piper and STABLER diagrams.

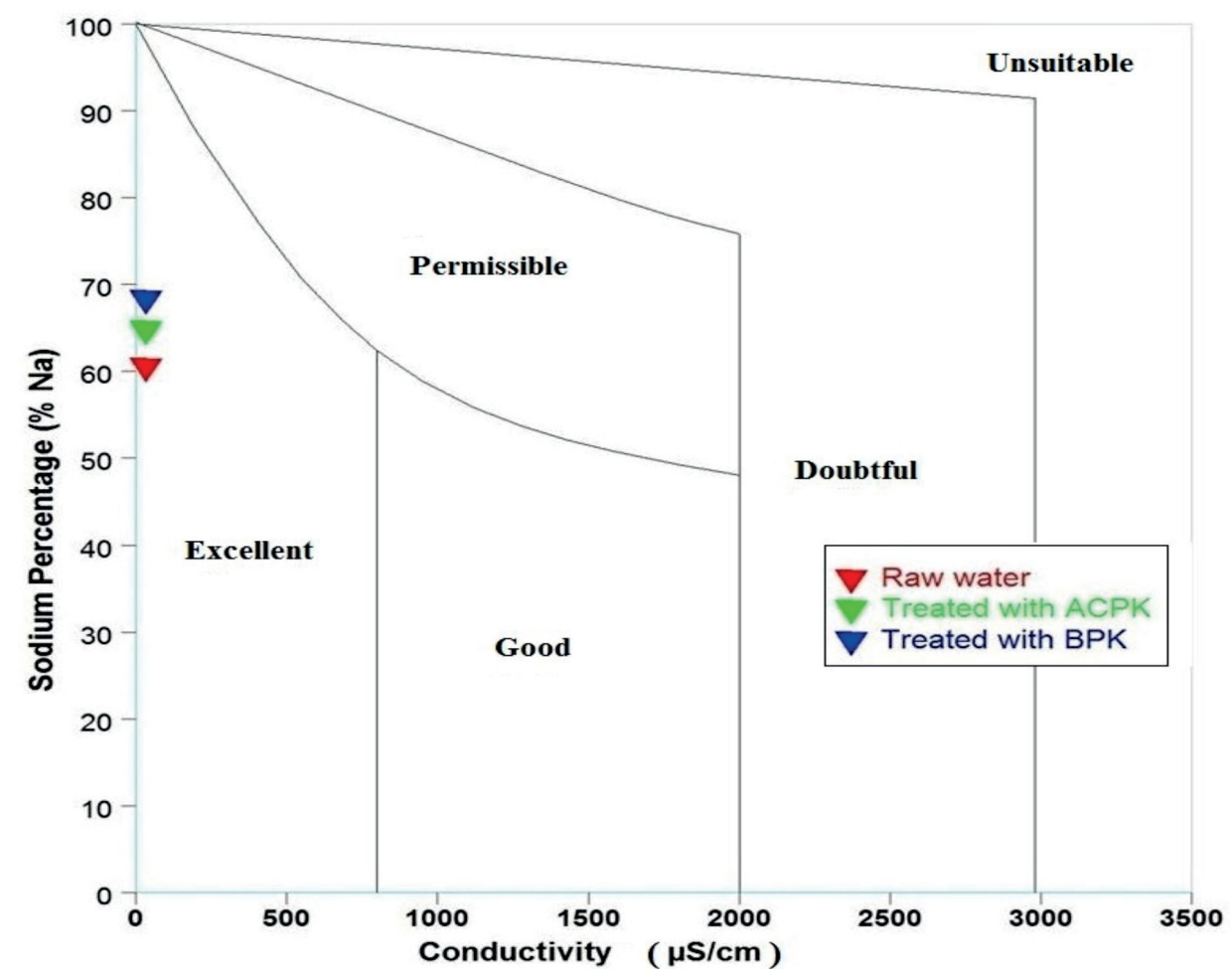

Fig. 7. Wilcox diagram showing the suitability of groundwater for irrigation. 


\section{Groundwater Suitability for Irrigation}

Fig. 7 shows that all the water samples have adjacent electrical conductivity values $(\approx 35$ microsimens/ $\mathrm{cm})$. The sodium percentage values increase from $60 \%$ for the contaminated water to $64 \%$ and $68 \%$ for the treated water samples with ACPK and BPK respectively, that is related to the increase of sodium and potassium concentrations presented on Schöeller Berkaloff diagram. All samples of water fall in the fresh water zone "Excellent" categories for irrigation purposes (Fig. 7). It can be concluded that the used adsorbents can eliminate organic pollution from the studied contaminated groundwater without changing its suitability for irrigation uses.

\section{Conclusions}

Biochar (BPK) and activated carbon (ACPK) were developed from palm kernel and used as low-priced materials to treat water samples contaminated with oil pollution. Several analysis techniques characterized the prepared materials, and their absorption efficiency was evaluated by measuring the $\mathrm{COD}$ and $\mathrm{BOD}_{5}$ concentrations before and after treatment. Results showed the ability of chemical activation in improving adsorptive characteristics of prepared biochar.

The COD removal for the BPK and ACPK samples reached $82.6 \%$ and $95.2 \%$, respectively, while the $\mathrm{BOD}_{5}$ removal efficiency was the same (97.0\%) for both adsorbents (for initial $\mathrm{BOD}_{5}=200 \mathrm{mg} / \mathrm{L}$ ). Further, prepared adsorbents showed a better ability to remove biologically oxidized organic pollution $\left(\mathrm{BOD}_{5}\right)$ compared to chemically oxidized organic pollution (COD) and in optimizing neutral values of $\mathrm{pH}$. Piper, STABLER, and Schöeller Berkaloff diagrams indicate that the adsorption manner does not change the hydrochemical type of the oil-contaminated water: sodium chloride type with a reduced presence of the other ions, Wilcox diagram showed that all the studied samples fall in the excellent category of suitability for irrigation with a weak change in sodium percentage.

Overall, the current study reveals that date kernel waste qualified as a suitable feed material for AC generation. Upon chemical treatment, adsorption capability improved, allowing the significant reduction of $\mathrm{COD}$ and $\mathrm{BOD}_{5}$ pollutant levels, accordingly better water quality favorable for irrigation use.

\section{Acknowledgments}

We want to thank the scientific and technical research center for arid regions (CRSTRA); Biskra, Algeria for the support of this work under the patronage of Directorate-General for Scientific Research and Technological Development (DGRSDT).

\section{Conflict of Interest}

The authors declare no conflict of interest.

\section{References}

1. JORDI P., JOAN A. Oil pollution in the Mediterranean. Springer. 84, 5, 2012.

2. SAIEN J., NEJATI H. Enhanced photocatalytic degradation of pollutants in petroleum refinery wastewater under mild conditions. Hazard. Mater. 148 (1), 491, 2007.

3. JULIUS S. An oil refinery in the North of Atlantic: environmental profile. Impact Assessment and Project Appraisal. 18 (4), 309, 2012.

4. WAKE H. Oil refineries: a review of their ecological impacts on the aquatic environment. Estuarine, Coastal and Self Sci. 62, 131, 2005.

5. CHINTAN P., MANDAliA H. C. Petroleum industries: environmental pollution effects, management and treatment methods. Int. J. Sep. Environ. Sci. 1 (1), 56, 2012.

6. ARIMORO F. O., UKU J. E., ODUME N. O. Effects of petroleum pollution in Niger Delta Wetlands: Interplay between the social and ecological systems. Kallel A., Ksibi M., Ben Dhia H., Khélifi N. (eds) Recent Advances in Environmental Science from the Euro-Mediterranean and Surrounding Regions. EMCEI 2017. Advances in Science, Technology \& Innovation (IEREK Interdisciplinary Series for Sustainable Development). Springer, Cham. 151, 2017.

7. KHADER EH., MOHAMMED THJ., MIRGHAFFARI N. Use of natural coagulants for removal of COD, Oil and turbidity from produced waters in the petroleum industry. J. Petrol. Environ.Biotechnol. 9 (3), 1, 2018.

8. AL-SHAMRANI A.A., JAMES A., XIAO H. Destabilisation of oil-water emulsions and separation by dissolved air flotation. Water Res. 36 (1), 1503, 2002.

9. GUANGJI H., LI J., HOU H. A combination of solvent extraction and freeze Thaw for oil recovery from petroleum refinery wastewater treatment Pond sludge. J. Hazard. Mater. 283 (1), 1, 2014.

10. LI Q., KANG C., ZHANG C. Waste water produced from an oilfield and continuous treatment with an oil-degrading bacterium. Process Biochem. 40 (1), 873, 2005.

11. MOHAMMED S.A.M., FAISAL I., ALWAN M.M. Oily wastewater treatment using expanded beds of activated carbon and Zeolite. Iraqui J. Chem. Pet. Eng. 12 (1), 2011.

12. TOMASZEWSKA M. Industrual wastewater treatment by means of memberane techniques. Pol. J. Environ. Stud. 9 (3), 138, 2007.

13. YONG S., YAOBIN Z., XIE Q. Treatment of petroleum refinery wastwater by microwave-assisted catalytic wet air oxidation under low temperature and low pressure. Sep. Purf. Techol. 62 (3), 565, 2008.

14. XIANGBIN L. Research progress on treatment technology of poduced water by adsorption method. IOP Conf. Ser.: Mater. Sci. Eng. 472 (1), 1, 2019.

15. GUPTA V.K., CARROTT P.J.M., RIBEIRO-CARROTT M.M.L. Low-cost adsorbents: growing approach to wastewater treatment-a review. Crit. Rev. Env. Sci. Technol. 39 (10), 783, 2009.

16. JAMALY S., GIWA A., HASAN S. W. Recent improvements in oily wastewater treatment: progress, challenges, and future opportunities. J. Environ. Sci. 37, 1, 2015. 
17. TRAN H.N., SHENG-JIE Y., NGUYEN T.V., CHAO H. Insight into the adsorption mechanism of cationic dye onto biosorbents derived from agricultural wastes. Chem. Eng. Commun. 204 (9), 1, 2017.

18. RAMIREZ A.P., GIRALDO S., ULLOA M., FLÓREZ E., ACELAS N.Y. Production and characterization of activated carbon from wood wastes. IOP J. Phys. Conf. Ser. 395 (4), USA, 2017.

19. FU K., YUE Q., GAO B., WANG Y., LI Q. Activated carbon from tomato stem by chemical activation with $\mathrm{FeCl}_{2}$. Colloids. Surf. A. 529, 1, 2017.

20. VILARDI G., DI-PALMA L., VERDONE N. Heavy metals adsorption by banana peels micro-powder: equilibrium modeling by non-linear models. Chin, J. Chem. Eng. 26 (3), 2018.

21. CHERIK D., LOUHAB K. A kinetics, isotherms, and thermodynamic study of diclofenac adsorption using activated carbon prepared from olive stones. J. Dispersion Sci. Techol. 39 (6), 1, 2017.

22. CHANGMAI M., BANERJEE P., NAHAR K., PURKAIT M.K. A novel adsorbent from carrot, tomato, and polyethylene terephthalate waste as a potential adsorbent for Co (II) from aqueous solution: Kinetic and Equilibrium studies. J. Environ. Chem. Eng. 6 (1), 2018.

23. HARAYAMA S., KISHIRA H., KASAI Y., SHUTSUBO $\mathrm{K}$. Petroleum biodegradation in marine environments. J. Molec. Microbiol. Biotechnol. 1 (1), 63, 1999.

24. SALIFU M., AIDOO F., HAYFORD M. S., ADOMAKO D., ASARE E. Evaluating the suitability of groundwater for irrigational purposes in some selected districts of the Upper West region of Ghana. Appl. Water Sci. 7, 2015.
25. KUMARASAMY P., DAHMS H., JEON H., RAJENDRAN A., JAMES R. A. Irrigation water quality assessment - an example from the Tamiraparani river, Southern India. Arab. J. Geosci. 7, 2013.

26. TAN I.A.W., HAMEED B.H., AHMAD A.L. Equilibrium and kinetic studies on basic dye adsorption by oil palm fiber activated carbon. Chem. Eng. J. 127, 111, 2007.

27. WANG S., ZHU Z.H., COOMES A., HAGHSERESHT F., LU G.Q. The physical and surface chemical characteristics of activated carbons and the adsorption of methylene blue from wastewater Shaobin. J. Colloid. Interface Sci. 284 (2), 440, 2004.

28. ZBAIR M., AHSAINE H.A., ANFAR Z. Porous carbon by microwave-assisted pyrolysis: An effective and lowcost adsorbent for sulfamethoxazole adsorption and optimization using response surface methodology. J. Cleaner Prod. 202, 571, 2018.

29. HUANG H., TANG J., GAO K., HE R., ZHAO H., WERNER D. Characterization of $\mathrm{KOH}$ modified biochars from different pyrolysis temperatures and enhanced adsorption of antibiotics. RSC. Adv. 24 (7), 14640, 2017.

30. TRAN H.N., LEE C., VU M.T., CHAO H. Removal of copper, lead, methylene green 5 , and acid red 1 by Saccharide-Derived spherical biochar prepared at low calcination temperatures: adsorption kinetics, isotherms, and thermodynamics. Water Air Soil Pollut. 228, 1, 2017.

31. INADA M., ENOMOTO N., HOJO J., HAYASHI K. Structural analysis and capacitive properties of carbon spheres prepared by hydrothermal carbonization. Adv. Powder Technol. 28 (3), 1, 2017. 